\title{
Pemberian Grasi dan Maaf dalam Bingkai Kajian Teoritik Tindak Pidana Pembunuhan (Studi Komparatif Hukum Positif dan Hukum Islam)
}

\author{
Asih Pusposari \\ Muhammadiyah University of Surakarta \\ Lawyer.pusposari49@gmail.com
}

\begin{abstract}
In the Criminal Code there are several differences that are the reasons for the review of theories and the application of reasons for clemency or forgiveness. The theories that form the basis of forgiveness will lead to different views. In connection with sources of clemency (Positive Criminal Law) and forgiveness (Islamic Criminal Law) have differences. Where clemency is the prerogative of the president as the temporary head of state, forgiveness can only be given by the heirs of the victim as the party who lost the victim. This study aims to find out where the justice is if the granting of pardon/apology is given by the president with only consideration from the Supreme Court. Meanwhile, in Islamic Law also regulates the apology for the perpetrators of the crime of murder which is the right of the heirs of the victim. This research is a qualitative research with the type of research used is library research. It is said as library research or document study because this research is mostly conducted on written regulations or other legal materials which are secondary in the library.
\end{abstract}

Keyword: Pardon, Forgiveness, and Crime of Murder

\begin{abstract}
Abstrak
Dalam KUHP terdapat beberapa perbedaan yang menjadi alasan dari tinjauan teori maupun penerapan alasan Grasi atau pemaaf. Teori-teori yang menjadi dasar tentang alasan pemaaf akan mengakibatkan pandangan yang berbeda. Sehubungan dengan sumber Grasi (Hukum Pidana Positif) dan Maaf (Hukum Pidana Islam) memiliki perbedaan. Dimana Grasi merupakan hak prerogatif presiden sebagai kepala Negara sementara itu, maaf hanya dapat diberikan oleh ahli waris korban selaku pihak yang kehilangan korban. Penelitian ini bertujuan untuk mengetahui dimana kah letak keadilan jika pemberian Grasi/Maaf diberikan oleh presiden dengan hanya pertimbangan dari Mahkamah Agung. Sementara itu, dalam Hukum Islam juga mengatur tentang pemberian maaf bagi pelaku tindak pidana pembunuhan yang merupakan hak dari ahli waris korban. Penelitian ini termasuk
\end{abstract}


penelitian Kualitatif dengan jenis penelitian yang digunakan adalah penelitian pustaka (library reseach). Dikatakan sebagai penelitian pustaka ataupun studi dokumen disebabkan penelitian ini lebih banyak dilakukan terhadap peraturan-peraturan yang tertulis atau bahan-bahan hukum yang lain yang bersifat sekunder yang ada di perpustakaan.

Kata Kunci: Grasi, Maaf, dan Tindak Pidana Pembunuhan

\section{Pendahuluan}

Sejak zaman dahulu, nyawa manusia merupakan suatu hal yang terpenting yang harus dilindungi, sehingga masalah nyawa ini sudah diatur oleh suku-suku primitif sekalipun. Meskipun demikian, jika dilihat ke belakang dalam perundang-undangan Hammurabi pada akhir abad ke-18 SM, pembunuhan maupun pembunuhan berencana bukanlah merupakan suatu delik. Pembunuhan menjadi suatu delik lahir dari hukum kebiasaan. Dalam masyarakat patriarki Babylonia, pembunuhan terhadap bapak dianggap sebagai salah satu delik yang terberat. Dalam hukum Taurat memukul bapak dan ibu diancam dengan pidana mati. (Sofian 2018, 229)

Secara bahasa pembunuhan diartikan dengan "proses, cara, perbuatan membunuh." (Nasional 2008, 1525) Di dalam literatur bahasa Arab pembunuhan diartikan dengan "menghilangkan ruh dari jasad (kematian)."(Muhammad, n.d., 393) Adapun secara yuridis, di Indonesia pembunuhan atau tindak pidana pembunuhan diatur dalam Kitab Undangundang Hukum Pidana (KUHP), yaitu Pasal 338 dan Pasal 340 yang dimuat dalam Bab XIX dengan judul "kejahatan terhadap nyawa orang lain."

Sementara itu dalam penjelasan Pasal 9 Undang-Undang No. 26 Tahun 2000 Tentang Pengadilan Hak Asasi Manusia menyatakan bahwa yang dimaksud dengan "Pembunuhan" adalah sebagaimana tercantum dalam Pasal 340 Kitab Undang-Undang Hukum Pidana. Pembunuhan dalam Pasal 340 KUHP adalah pembunuhan berencana. (M. dan S. N. Ali 2011, 150) Berbeda dengan pembunuhan dalam pengadilan untuk bekas Yugoslavia yang diartikan bukan sebagai pembunuhan berencana. Perumusan pembunuhan yang mensyaratkan adanya perencanaan sebelumnya memberatkan pembuktian. Sebuah kejahatan pembunuhan yang merupakan bagian dari serangan yang meluas, harus pula dibuktikan sebagai pembunuhan berencana yang bagian terakhirnya merupakan bagian dari pembuktian unsur sistematis.

Dalam Hukum Positif Indonesia, kita mengenal adanya hukuman mati atau pidana mati. Kitab Undang-Undang Hukum Pidana (KUHP) Bab II mengenai pidana, Pasal 10 dinyatakan mengenai macam-macam pidana, yaitu terdiri dari pidana pokok dan pidana tambahan. Pidana mati termasuk jenis pidana pokok yang menempati urutan pertama. (Chazawi 2002, 25) Pidana mati adalah pidana yang terberat dari semua pidana, yang 
hanya diancamkan kepada kejahatan kejam. Pidana mati dianggap pidana yang paling tua, sehingga menimbulkan pro dan kontra terhadap penggunaannya.(Gustiani, Diah 2013, 43)

Sementara itu, hukuman mati dalam Islam merupakan ketentuan yang telah ditetapkan Allah untuk mencegah kejahatan demi kelangsungan hidup manusia serta sebagai perlindungan terhadap qishash ini merupakan jenis hukuman mati dalam Islam bagi tindak pidana pembunuhan sengaja. Pada dasarnya qishash adalah balasan (hukuman) bagi seorang pelaku kejahatan sesuai dengan perbuatan yang dilakukannya atau pembalasan setimpal dari suatu tindakan perbuatan yang dilakukan secara sengaja.('Audah 1963, 14)

Pembunuhan diartikan oleh para ulama sebagai perbuatan manusia yang menyebabkan hilangnya nyawa. Dalam Islam juga dikenal adanya hukum pidana yang dikenal dengan qishash. Bila ia melakukan pembunuhan, maka ia akan dihukum mati, bila ia melukai anggota tubuh korbannya, maka ia akan mendapat pembalasan dengan dilukai anggota tubuhnya seperti luka yang diderita korbannya. Sayangnya selama ini banyak kalangan yang menganggap bahwa Hukum Pidana Islam adalah hukuman yang kejam, tidak manusiawi dan tidak menghormati hak-hak atas manusia. Karena Hukum Pidana Islam hanya dipelajari secara parsial, belum menyeluruh sehingga menimbulkan persepsi bahwa qishash adalah hukum yang tidak berperikemanusiaan.(Arifin 2016, 172)

Hukuman qishash dalam masalah tindak pidana disyariatkan untuk memelihara jiwa, karena seorang yang hendak melakukan kejahatan manakala ia mengetahui akan dibalas dengan perbuatan yang serupa, niscaya dirinya tercegah melakukan tindakan jahatnya. Dengan demikian, terpeliharalah jiwanya dan juga jiwa orang yang sedang diincar. Akan tetapi, dengan adanya sanksi hukuman pembalasan atau pemaafan (dari wali si terbunuh), maka di akhirat tidak ada tuntutan lagi (bagi pelakunya).(Al-Fannani 2013, 1512)

Grasi merupakan salah satu hak prerogatif Presiden sebagai kepala Negara dalam bidang yudikatif. Grasi sangat dibutuhkan dalam pemerintahan suatu Negara karena dapat meminimalisasi beberapa resiko yang dikhawatirkan sebagai akibat dari vonis yang dijatuhkan oleh hakim, khususnya untuk pidana maksimal seperti pidana mati, yaitu adanya kemungkinan terjadi eksekusi terhadap innocent people.

\section{Metode}

Penelitian ini termasuk penelitian Kualitatif dengan jenis penelitian yang digunakan adalah penelitian pustaka (library reseach).(Supranto 2003, 2) Dikatakan sebagai penelitian perpustakaan ataupun studi dokumen disebabkan penelitian ini lebih banyak dilakukan terhadap data yang bersifat sekunder yang ada di perpustakaan.(Dillah 2013, 51) Pendekatan yang digunakan dalam penyusunan penelitian ini adalah pendekatan perundang-undangan (Statue Approach), pendekatan konsep (Conseptual Approach), dan pendekatan perbandingan (Comparative approach). 
Sumber data dalam penelitian ini adalah subyek darimana data dapat diperoleh. Data primer ialah data yang diperoleh langsung dari sumbernya, baik melalui wawancara, observasi maupun laporan dalam bentuk dokumen tidak resmi yang kemudian diolah oleh peneliti.(Z. Ali 2010, 106) Subjek dari penelitian ini adalah Para praktisi Hukum, sedangkan Objek penelitian ini adalah Undang-undang No. 5 Tahun 2010 Tentang Grasi serta dalil-dalil dalam Hukum Islam yang berkenaan dengan hak pemberian maaf dan qishash atas tindak pidana pelaku pembunuhan.

Dalam menganalisis data, peneliti menggunakan analisa data secara komparasi, yaitu menganalisa data dengan memakai unsur-unsur sistem hukum sebagai titik tolak perbandingan.(Sunggono 2013, 96) Perbandingan hukum dilakukan dengan membandingkan Undang-Undang satu Negara dengan Undang-Undang Negara lain mengenai perkara yang sama. Dari perbandingan yang dilakukan akan ditemukan persamaan maupun perbedaannya (Susanti 2015, 134), menemukan letak keadilan antara pertimbangan yang diberikan oleh Mahkamah Agung serta oleh ahli waris korban.

\section{Hasil dan Pembahasan}

Untuk mempermudah kita dalam memahami perbandingan pemberian Grasi dan Maaf kepada pelaku tindak Pidana Pembunuhan, maka peneliti akan mengklasifikasikan tentang beberapa hal yang akan dibandingkan:

\section{A. Grasi Perspetif Hukum Positif}

\section{Kewenangan Memberi Grasi}

Pada zaman kerajaan absolut Eropa, awalnya pemberian ampunan oleh raja adalah dalam bentuk anugerah raja (vorstelijke gunst) yang diberikan kepada terpidana. Artinya bahwa raja memberikannya sebagai bentuk kemurahan hati sang raja bukan sebagai salah satu upaya hukum. Seiring berkembangnya jaman, dimana kekuasaan kehakiman telah berpisah dari kekuaasaan pemerintahan atas pengaruh paham trias politica, maka pemberian ampunan (grasi) menjadi salah satu bentuk koreksi terhadap putusan hakim pengadilan terkhusus pada proses pelaksanannya. (Lestaluhu 2017, 129)

Berdasar pada Undang-undang No. 22 Tahun 2000 Jo Undang-undang No. 5 Tahun 2010 tentang Grasi dirumuskan bahwa grasi adalah bentuk pengampunan berupa perubahan, peringanan, pengurangan atau penghapusan pelaksanaan pidana kepada pelaku pidana yang diberikan oleh presiden. Dalam hal ini yang dimaksud pelaku pidana adalah seseorang yang oleh keputusan hakim pengadilan dipidana dengan keputusannya telah memperoleh kekuatan hukum tetap.(Priyanto 2012, 138)

\footnotetext{
al-aḥ̂âm Vol. 5, Nomor 1, 2020
} 
Pemberian grasi sebagai bentuk meringankan sanksi hukuman terpidana yang telah ditetapkan oleh keputusan hakim pengadilan. Grasi pada awalnya adalah pemberian atas kemurahan hati raja atas kekuasaan mutlak yang dimilikinya, namun seiring berkembangnya jaman grasi tidak lagi berbentuk seperti itu karena hak istimewa telah diberikan kepada pemerintah dan disini menjadi tanggungjawab kepala Negara atau di tangan presiden dalam sistem pemerintahan presidensiil.(Lestaluhu 2017, 136) Dalam sistem pemerintahan presidensiil puncak kepemimpinan baik tugas dan wewenangnya ada di tangan presiden. Namun tetap saja ada tugas dan wewenang yang menjadi lingkup pemerintahan dan juga kewenangan diluar pemerintahan.

Kewenangan di luar lingkup pemerintahan tersebut misalnya kewenangan dalam bidang yudisial. Kewenangan ini bisa berupa pemberian pengampunan dalam bentuk pengurangan sanksi hukuman atau menghapus tuntutan yang berkaitan dengan kewenangan pengadilan.(Lestaluhu 2017, 137)

Pemberian grasi oleh presiden bukan merupakan bentuk dari perbaikan bagi pelaku tindak pidana kejahatan. Selain itu. Pemberian grasi juga bukan merupakan bentuk penghapusan kesalahan dan atau melawan hukum yang telah dilakukan oleh terpidana, hingga hingga suatu saat pelaku dikhawatirkan akan melakukan perbuatan yang sama (residivis) dijadikan bahan pertimbangan dalam mengambil keputusan yang dilakukan oleh hakim pengadilan.

Dengan adanya pemberian grasi oleh presiden yang telah mengajukannya dapat dijadikan sebagai sarana untuk memperbaiki diri bagi pelaku tindak pidana. Karena bagi terpidana yang memperoleh sanksi berupa hukuman mati, grasi merupakan persoalan hidup dan mati. Dengan adanya grasi, bagi sanksi hukuman mati dapat berubah menjadi hukuman seumur hidup atau pengurangan hukuman dari yang sebelumnya dan atau penjara dengan waktu tertentu. Berbeda hal nya dengan tidak adanya pengajuan grasi, maka bagi pelaku tindak pidana tidak akan ada kesempatan untuk dirinya memperbaiki diri dari kesalahan yang telah diperbuatnya.(Lestaluhu 2017, 103)

\section{Siapa yang Berhak Memberikan Pertimbangan dalam Pemberian Grasi}

Dalam Pasal 14 ayat (1) UUD 1945 telah dirumuskan bahwa pemberian grasi dan rehabilitasi adalah merupakan bentuk hak prerogatif dari presiden, begitu hal nya dalam Pasal 35 Undang-Undang Nomor 14 Tahun 1985 tentang Mahkamah Agung "Presiden selaku kepala Negara dalam memberikan grasi mendapat nasehat dari Mahkamah Agung dalam rangka pemberian atau penolakan grasi." (UndangUndang Nomor 14 Tahun 1985 Tentang Mahkamah Agung (Lembaran Negara 
Republik Indonesia Tahun 1985 Nomor 73, Tambahan Lembaran Negara Republik Indonesia Nomor 3316), n.d.), itu artinya bahwa kewajiban dalam memberikan pertimbangan kepada presiden diberikan sepenuhnya kepada Mahkamah Agung apabila ada pengajuan grasi, rehabilitasi, amnesti dan abolisi.

Mahkamah Agung sebagai lembaga peradilan tertinggi adalah lembaga yang paling tepat dalam memberikan pertimbangan kepada presiden dalam memberikan grasi karena yang menyangkut putusan hakim adalah grasi, sementara rehabilitasi belum tentu menyangkut dengan putusan hakim.(Huda 2013, 198)

Ada dua alasan mengapa Mahkamah Agung perlu memberikan pertimbangan kepada presiden dalam hal pengajuan grasi dan rehabilitasi ialah pertama, biasanya pemberian grasi dan rehabilitasi diberikan kepada orang yang sudah melalui proses karena grasi dan rehabilitasi termasuk dalam proses yustisial sementara amnesti dan abolisi lebih bersifat kepada politik. Kedua, pengajuan grasi dan rehabilitasi kebanyakan diajukan oleh perseorangan sementara amnesti dan abolisi biasanya diajukan banyak orang.(Yusuf 2000, 190)

Dalam hal ini yang di maksud dengan pemberian pertimbangan Mahkamah Agung dalam mengabulkan atau menolak permohonan grasi oleh presiden adalah agar tepat sesuai fungsinya sebagai lembaga yudikatif. Pemberiaan pertimbangan oleh Mahkamah Agung terhadap pengajuan permohonan grasi memberikan batasan terhadap penyalahgunaan kekuasaan oleh presiden sebagai kepala Negara sehingga tidak adanya pemberian grasi yang berlebihan terhadap terpidana sanksi hukuman yang berat. Dalam hal pertimbangan apa yang digunakan dalam memberikan pertimbangan oleh Mahkamah Agung terhadap keputusan presiden adalah pertimbangan diluar hukum yang menyangkut dengan kemanusiaan yang mengedepankan persamaan di depan hukum dan juga adanya kepastian hukum. Sementara itu, dalam hal implikasi hukum pemberian grasi oleh presiden terhadap terpidana adalah tidak berkaitan dengan putusan pengadilan serta tidak memperberat hukuman tersebut baik itu permohonan yang diterima ataupun ditolak.

Jadi, masukan/nasehat dari Mahkamah Agung sebagai lembaga yang kompeten dibidang tersebut sangat diperlukan oleh presiden dalam memberikan keputusan permohonan grasi terhadap pelaku tindak pidana. oleh karena itu, menjadi hal yang sangat penting pertimbangan Mahkamah Agung dalam memberikan pertimbangan keputusan presiden terhadap pengajuan grasi yang harus mempertimbangkan masalah pembalasan dan juga mengenai perlindungan tertib hukum terhadap masyarakat. 


\section{Prosedur dalam Permohonan Grasi}

Dalam Undang-Undang Nomor 22 Tahun 2002 jo Undang-Undang Nomor 5 Tahun 2010 tentang grasi pada Bab III disebutkan tentang prosedur dalam pengajuan permohonan grasi ialah:

- Hak pengajuan permohonan grasi disampaikan kepada terpidana oleh hakim atau hakim ketua sidang yang memutus perkara pada tingkat pertama(UndangUndang No. 22 Tahun 2002, n.d., Pasal 5 ayat (1)) atau jika ternyata terpidana tidak hadir maka akan diberitahukan secara tertulis oleh panitera pengadilan yang memutus perkara pada tingkat pertama.(Undang-Undang No. 22 Tahun 2002, n.d., Pasal 5 ayat (2))

- Bahwa pengajuan permohonan grasi dapat dilakukan oleh terpidana secara langsung, baik itu lewat kuasa hukum atau keluarganya dengan persetujuan terpidana.(Undang-Undang No. 22 Tahun 2002, n.d., Pasal 6 ayat (1-3))

- Pengajuan permohonan grasi dapat dilakukan oleh keluarga dengan atau tanpa persetujuan pelaku tindak pidana jika sanksi hukuman berupa hukuman mati. (Undang-Undang No. 22 Tahun 2002, n.d., Pasal 6 ayat (3))

- Sejak ditetapkannya putusan yang berkekuatan hukum tetap oleh pengadilan maka pada saat itu juga pengajuan grasi boleh diajukan serta tidak adanya pembatasan waktu tertentu.(Undang-Undang No. 22 Tahun 2002, n.d., Pasal 7)

- Pengajuan permohonan grasi ini diajukan secara tertulis melalui pengadilan tingkat pertama yang memutus perkara tersebut untuk diteruskan ke Mahkamah Agung dan kemudian mendapat jawaban dari presiden atau melalui kepala lembaga pemasyarakatan tempat terpidana menjalani hukumannya untuk disampaikan kepada presiden dengan salinan yang ditembuskan kepada pengadilan tingkat pertama, di mana perkara tersebut diputuskan.

Sebagaimana dikemukakan di atas, bahwa presiden berhak mengabulkan atau menolak permohonan grasi yang telah diajukan terpidana.(Undang-Undang No. 22 Tahun 2002, n.d., Pasal 4 ayat (1)) Jangka waktu proses permohonan grasi memang ditentukan dalam aturan perundang-undangan, sebagai berikut:

- 20 hari paling lambat sejak salinan diterima oleh Pengadilan Tingkat untuk proses penyerahan salinan pertama ke Mahkamah Agung;

- 3 bulan paling lambat sejak diterima oleh Mahkamah Agung mengirimkan pertimbangannya ke Presiden;

- 3 bulan sejak diterimanya pertimbangan oleh Mahkamah Agung, presiden harus memberikan keputusan memberikan grasi atau menolaknya; dan

- 14 hari sejak putusan dibuat, maka harus diberitahukan kepada terpidana yang bersangkutan. 


\section{B. Pemberian Maaf Perspektif Hukum Islam}

\section{Kewenangan dalam Memberikan Maaf}

Dalam Hukum Islam tidak dijelaskan secara spesifik tentang siapakah orang yang berhak memberikan maaf terhadap pelaku tindak pidana yang diancam dengan hukuman mati atau qishash sebagaimana yang telah dijelaskan secara spesifik dalam hukum positif serta bagaimana mekanismenya. Akan tetapi, berdasarkan surah Al-Baqarah ayat 178 dapat kita simpulkan bahwa orang yang berhak memberikan maaf atau pengampunan terhadap terpidana mati (qishash) ialah ahli waris/ keluarga korban. Ahli waris korban bisa saja mengambil langkah untuk memaafkan secara keseluruhan atau memaafkan dengan membayar diyat dan atau justru sepakat untuk di qishash.

Imam Qurthubi berkata, "Tidak ada yang berbeda pendapat bahwa hak qishash itu hanya dimiliki oleh para pewaris korban. Merekalah pihak yang diperbolehkan untuk menuntut pelaksanaan qishash atau sanksi-sanksi yang lain. Hal ini karena Allah Swt meminta seluruh umat muslimin untuk memberlakukan qishash. Tetapi, seluruh umat muslimin tidak mungkin untuk melakukan hal itu pada satu waktu. Karena itu, umat muslim memilih pihak yang berkuasa untuk mewakilkan mereka dalam pemberlakuan qishash dan semua sanksi yang berkaitan dengan hak-hak Allah Swt."(Munajat 2009, 175)

Hakim juga diminta untuk menyelidiki benda yang digunakan untuk pelaksanaan qishash (jika para keluarga korban memilih qishash). Tindakan preventif ini dilaksanakan karena dikhawatirkan pemberlakuan qishash akan menyiksa sang korban. Selain itu, hakim juga harus menyerahkan pelaksanaan qishash kepada orang yang cakap dalam bidang ini (algojo khusus). Biaya pelaksanaan diambil dari kas baitul mal.(Munajat 2009, 316)

Apabila orang yang terbunuh memiliki dua wali, lalu keduanya menetapkan untuk menuntut pelaksanaan qishash atas pembunuh atau keduanya belum mengambil keputusan hingga salah satunya berkata "Aku telah memberi maaf kepada pembunuh karena Allah", "Aku telah memberi maaf kepadanya", "Aku telah mencabut tuntutan pelaksanaan qishash", atau pembunuh berkata "Berilah aku maaf", lalu si wali berkata "Aku telah memberi maaf kepadamu", maka gugurlah hukuman qishash dari orang itu. Namun wali yang memberi maaf tetap berhak mendapatkan diyat (denda), karena pencabutan tuntutan atas pelaksanaan qishash bukan berarti pencabutan tuntutan terhadap diyat (denda). Bahkan yang dimaafkan disini hanya satu dari dua perkara, bukan kedua-duanya.(Idris 2013, 659) Allah Swt berfirman: 
Maka barangsiapa mendapatsuatu pemaafan darisaudaranya, hendaklah (yang dimaafkan) mengikuti dengan cara yang baik, dan hendaklah (yang diberi maaf) membayar (diyat) kepada yang memberi maaf dengan cara yang baik pula. (QS. Al-Baqarah (2): 178).

Qishash selain merupakan hak ahli waris korban, disamping memiliki hak menuntut balas kematian, mereka juga mempunyai hak untuk memaafkan. Jika mereka memaafkan, maka berdasarkan kesepakatan ulama, hukum qishash gugur, karena qishash adalah kewenangan penuh mereka, sehingga bisa gugur dalam pemaafan mereka. Sebagai gantinya, mereka berhak mendapatkan diyat dari pelaku yang tidak di qishash. Hal ini sesuai sabda Nabi Saw:

Barangsiapa yang dibunuh, maka keluarganya dapat memilih diantara dua hal: jika mau mereka dapat menuntut hukuman mati, dan jika mau mereka dapat mengambil diyat.(Idris 2013, 659)

Diyat di sini bukanlah sesuatu kewajiban karena kasus pembunuhan, melainkan sebagai pengganti dari qishash, meskipun tanpa kerelaan dari terpidana. Oleh karena itu, keluarga korban boleh membuat kesepakatan damai sebagai ganti selain diyat.

\section{Siapa yang Berhak Memberi Pertimbangan dalam Memberikan Maaf}

Di dalam Al-qur'an telah dijelaskan bahwa yang dimaksud dengan qishash adalah sanksi hukum yang ditetapkan kepada pelaku tindak pidana sama halnya dengan apa yang telah dilakukannya terhadap si korban sebelumnya. Menuntut qishash merupakan hak bagi pewaris korban. Tetapi, dalam pelaksanaanya, qishash hanya dapat dilakukan di bawah otoritas hakim.(Sabiq 2012, 315)

Hukuman qishash dalam Al-Qur'an merupakan hukuman tertinggi, sehingga dalam kasus tertentu hakim dapat menentukan hukuman yang lebih rendah terhadap pelaku tindak pidana atas persetujuan ahli waris korban. Hukum diyat (ganti rugi), ta'zir berupa penjara atau bahkan pembebasan (maaf) merupakan hal yang sangat mungkin diterapkan dalam masalah pembunuhan. Intinya ialah pada penerapan sanksi tersebut karena bisa dijalankan secara kondisional. Termasuk dalam jenis pembunuhan apa, siapa pelaku pembunuhan, serta alasan pelaku melakukan perbuatan tersebut. Hal tersebut dapat dijadikan pertimbangan oleh hakim dalam memberikan keputusan terhadap pelaku tindak pidana. Pendapat ini disampaikan oleh Muhammad Syahrur dalam teori batas maksimalnya (halah alhad al-a'la).(Munajat 2009, 175)

Sementara itu, orang yang berhak dalam memberikan pertimbangan maaf adalah ahli waris korban dengan maksud untuk menghapus dosa pelaku tindak 
pidana kejahatan. Sebagaimana perintah Allah dalam surat Al-Maidah ayat 45 yang berbunyi:

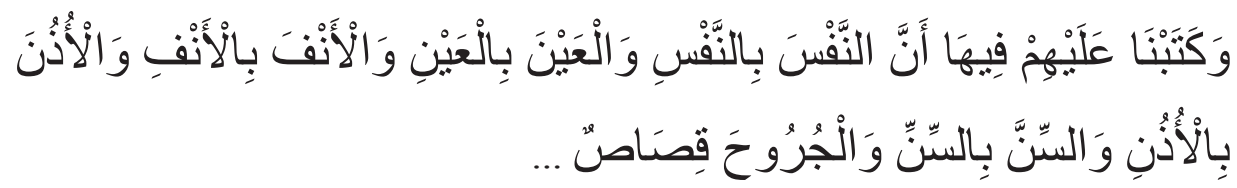

Dan kami telah tetapkan terhadap mereka di dalamnya (At-Taurat) bahwasanya jiwa (dibalas) dengan jiwa, mata dengan mata, hidung dengan hidung, telinga dengan telinga, gigi dengan gigi, dan luka-luka pun ada qishashnya ... (Qs. Al-Maidah: 45)

Imam Abu Nashr bin ash-Shabbagh dalam kitabnya Asy-Syamil menjelaskan tentang ijma' para ulama tentang kesepakatan mereka terhadap penggunaan ayat tersebut diatas sebagai hujjah. Para ulama telah sepakat menggunakan keumuman ayat tersebut sebagai hujjah dalam kasus pembunuhan yang dilakukan seorang lelaki terhadap seorang wanita maka ia harus diberi sanksi berupa hukuman mati. Apa yang disampaikan Ibnu Shabbagh tentang penggunaan ayat tersebut sebagai hujjah diperkuat dengan adanya hadis yang berkaitan dengan masalah ini. Hadis tersebut berbunyi:

Sebagaimana yang telah diriwayatkan oleh Imam Ahmad dari Anas bin Malik, bahwa bibinya, Rabi' pernah mematahkan gigi seri seorang budak wanita. Kemudian keluarganya meminta maaf kepada keluarga pemilik budak itu, namun mereka menolaknya. Kemudian mereka mendatangi Rasulullah Saw, maka beliau bersabda: "Berlakukan qishash." Lalu saudara laki-laki Rabi', Anas bin Nadhir berujar: "Ya Rasulullah, apakah dipatahkan pula gigi si fulanah!" Maka beliau bersabda: "Hai Anas, ketetapan Allah adalah qishash." Maka Anas bin Nadhir berkata: "Demi Allah yang mengutusmu dengan haq, tidak dipatahkan gigi si fulanah."(Syaikh 2017, 121)

Dengan demikian orang tersebut ridho dengan perintah Allah sehingga ia memberikan maaf terhadap pelaku tindak pidana dan tidak menuntut qishash terhadap apa yang telah diperbuatnya.

Solusi yang telah diberikan oleh Al-qur'an tersebut berupa pemberian kebebasan kepadaahliwaris korban untukmenuntut balasterhadap pelakukejahatan dalam bentuk diyat (materi). Alqur'an juga memerintahkan untuk memberikan maaf dimana bentuk pemberian maaf merupakan sebuah kebijakan yang sangat mulia dan bernilai tinggi. Solusi yang diberikan ini memberikan anggapan bahwa kejahatan pembunuhan merupakan bentuk dari kejahatan yang bersifat personal. Sementara dalam surah lain yaitu surah Al-Maidah ayat 32 menjelaskan dengan 
pasti bahwa kejahatan pembunuhan sebagai bentuk kejahatan yang bersifat luas bukan hanya terhadap ahli waris korban karena kejahatan pembunuhan termasuk kejahatan terhadap kemanusiaan.

Dari Abu Hurairah beliau berkata, Rasulullah Saw bersabda,

...barangsiapa mendapati keluarganya dibunuh maka dia berhak memilih dua perkara, antara diyat dan qishash. (HR. Al-Bukhari dalam Fathul Barri bi syarah Shahih Al-Bukhari, Al-Asqalany 1997, jilid 14, Hadis No. 6880, hal. 188).

Hadis tersebut memberikan penjelasan bahwa ahli waris korban mempunyai dua hak pilihan yang berupa menuntut qishash atau memberikan maaf. Itu artinya bahwa qishash bukanlah alternatif tunggal.

Hukuman qishash memperlihatkan bahwa hukuman tersebut termasuk dalam hukuman yang sangat tegas namun sangat memperhatikan serta memperhitungkan nilai kemanusiaan. Hal ini terlihat jelas terlihat dari hadis diatas yang menunjukkan adanya kebolehan dalam bermusyarah dan bernegosiasi antara keluarga korban serta keluarga pelaku kejahatan. Namun dalam musyawarah tersebut keputusan akhirnya tetap diserahkan kepada keluarga korban.

Secara logika, ahli waris korban pembunuhan dengan pasti akan menuntut pembalasan yang sepadan atau dikenal istilah "hutang nyawa dibayar degan nyawa". Dari kacamata keadilan, hukuman sepadan menjadi hukuman yang sangat tepat bagi orang yang membunuh diperlakukan sama seperti apa yang telah ia perbuat terhadap orang lain. Dari kacamata kemaslahatan, agar tercipta kehidupan yang aman, damai dan juga tentram serta sebagai upaya memelihara jiwa manusia, maka hukuman qishash bagi pelaku pembunuhan adalah hukuman yang sangat tepat. Logika tersebut berdasarkan pada dalil:

Dan dalam qishash itu ada (jaminan kelangsungan) hidup bagimu, hai orang-orang yang berakal. (QS. Al-Baqarah: 179)

Dalam ayat diatas dapat dikaji penggunaan terminologi ulul albab dalam konteks qishash merupakan hal yang menarik. Ulul albab dalam ayat diatas menggambarkan bahwa seseorang dapat dengan maksimal dalam menggunakan daya pikir secara luas dan tinggi demi menemukan maksud dan tujuan Allah dalam mewajibkan pemberlakuan hukuman qishash. Setelah pengkajian secara mendalam maka akan ditemukan alasan yang utama Allah dalam mewajibkan hukuman qishash yaitu berupa jaminan kelangsungan hidup manusia.(Purbalin 2015, 39)

Dalam hukuman qishash tanpa kita sadari terdapat sebuah kelenturan dalam implementasi hukuman. Hal itu terlihat dengan adanya peluang negosiasi antara 
keluarga korban dan juga keluarga pelaku pembunuhan. Mereka dapat memilih serta menyepakati memilih antara balas nyawa (qishash), diyat (ganti rugi denda) atau justru memaafkan tanpa disertai diyat. Sementara itu, posisi hakim dalam hal ini adalah hanya sebagai pelaksana saja tanpa bisa memilihkan hukuman bagi mereka karena belum tentu apa yang dipilihkan oleh hakim dalam keputusannya nanti menjadi suatu keadilan bagi keluarga korban maupun pelaku.

Dengan adanya 3 (tiga) pilihan diatas, menandakan bahwa penjara bukanlah solusi yang tepat baik bagi keluarga korban maupun keluarga terpidana. Karena dengan penjara justru membatasi produktivitas terpidana dan belum tentu menjadi jera dan juga dengan sanksi berupa penjara bisa jadi justru merugikan keluarga korban karna subjektivitas hakim atas keputusannya. Penjara dewasa ini justru sebagai sarana mengembangkan kejahatan serta bisa menambah beban bagi anggaran Negara nantinya. Dengan demikian, qishash sebagai solusi praktis dan juga mudah dalam menyelesaikan permasalahan secara cepat dan tuntas pada substansinya.

M. Quraish Shihab berpendapat dalam kitab tafsirnya bahwa kata 'awf diartikan sebagai kata "maaf", dengan kata lain ialah "menghapus".(Shihab 2002, 207) Menurut M. Qurais Shihab, memaafkan artinya ia telah menghapus kesalahan serta bekas luka yang ada dalam hatinya dikarenakan perbuatan yang telah dilakukan orang lain kepada dirinya. Sama hal nya dengan Ibnu Katsir yang berpendapat dalam kitab tafsirnya bahwa kata awf dimaknai dengan memaafkan kesalahan orang lain sehingga tidak ada sama sekali niat dalam dirinya untuk membalas perbuatan orang yang telah menyakitinya.(Katsir 2004, 142)

\section{Prosedur dalam Mengajukan dan Memberi Maaf}

Allah dalam menetapkan Hukum Islam disesuaikan berdasarkan sifat kemanusiaan (Insaniyah) dimana hukum tersebut sebagai sunnatullah dan tidak akan mengalami perubahan disebabkan adanya perubahan jaman. Oleh sebab itu, sampai sejauh ini tidak ditemukan penjelasan secara rinci dan hierarkis bagaimana tata cara pengajuan maaf terhadap korban pembunuhan sebagaimana yang terdapat di dalam Hukum Positif.

Karena sifat kemanusiaan manusia yang tidak mengalami perubahan sampai akhir, sehingga Islam memberikan hak kepada korban atau ahli warisnya untuk menuntut sepadan dengan kejahatan yang telah ia alami juga diberikan hak untuk memberi maaf kepada pelakunya dengan proses yang adil dan penuh maslahat. Pengajuan maaf dalam Islam begitu sederhana tidak sama seperti proses pengajuan upaya hukum lainnya seperti dalam hukum positif, hal ini terjadi dikarenakan 
masing-masing memiliki dasar yang berbeda-beda.(Raftanzani 2016, 95)

Dari Al-qur'an dan sunah yang telah dibahas pada bab sebelumnya disini peneliti memberi kesimpulan bahwa pemberian maaf dan atau penjatuhan hukuman qishash terhadap pelaku pembunuhan terletak pada ahli waris korban, dimana pertimbangan dalam memberikan maaf oleh ahli waris korban (dari segi eksternal maupun internal) terhadap pelaku tindak pidana pembunuhan dalam rangka mendekatkan diri kepada Allah Swt. Selain karena alasan tersebut, ahli waris korban memberikan maaf juga dalam rangka menjaga kelangsungan hidup bagi pelaku pembunuhan. Karena dengan adanya pelaksanaan qishash pun, pelaku tidak bisa menghidupkan korban pembunuhan kembali.

Karena pada bab sebelumnya pula telah dijelaskan siapa dan ditujukan untuk siapa pengajuan permohonan maaf dalam Islam telah jelas yaitu kepada ahli waris korban. Dalam hal ini ahli waris korban memberikan dua kemungkinan yaitu memberi maaf (membayar diyat) atau tidak memaafkan (menuntut qishash) terhadap pelaku pembunuhan.

Dalam Hukum Pidana Islam, baik yang berasal dari Al-quran maupun sunah tidak terdapat penjelasan secara rinci dan jelas mengenai kapan pengajuan permohonan maaf diajukan, berapa kali boleh mengajukan permohonan maaf serta berapa lama waktu yang dibutuhkan untuk menunggu keputusan atas pengajuan permohonan maaf. Hal ini menurut penulis dikarenakan kesederhanaan dalam sistem peradilan baik itu perdata maupun pidana yang dijalankan pada masa zaman dahulu.

Abdul Wahhab Khallaf menyampaikan bahwa pada zaman dahulu belum terdapat kantor peradilan serta undang-undang yang mengatur tentang sistem peradilan secara terperinci seperti pada zaman sekarang ini sehingga proses peradilan pun berlangsung secara sederhana dan singkat. Selain itu, kalau terjadi tindak pidana pembunuhan, Rasulullah Saw bertindak langsung sebagai hakim untuk memutuskan suatu perkara tanpa ada bantuan dari seorang jaksa, panitera maupun sekretaris. Jika ada seseorang yang mendapatkan permasalahan, ia bisa langsung menemui Rasulullah untuk meminta keputusan tanpa harus menunggu jangka waktu tertentu maupun memcari tempat tertentu pula.(Khallaf 1998, 42)

Berhubungan dengan pelaksanaan peradilan yang dilakukan oleh Nabi Muhammad Saw secara langsung dijelaskan dalam hadis yaitu:

Telah menceritakan kepada kami Yahya bin Yahya at-Tamimi, menceritakan kepada kami Abu Mu'awiyah, dari Hisyam bin Urwah, dari bapaknya, dari Zainab binti Abu Salamah, dari Ummu Salamah berkata: Rasulullah Saw. bersabda: "Sesungguhnya kalian telah bersengketa di hadapanku, 
dan bisa jadi sebagian kalian lebih lihai dalam mengajukan alasannya dari pada orang lain, lalu aku memutuskan perkara tersebut sesuai dengan yang aku dengar darinya, maka bila aku telah memutuskan hak kepada seseorang maka janganlah kalian mengambilnya kembali, karena sesungguhnya aku telah memberinya potongan api neraka."

Selain Nabi Muhammad Saw, seringkali ada beberapa sahabat/orang yang juga diangkat oleh Rasulullah menjadi seorang hakim dalam suatu permasalahan. Meskipun demikian, hal tersebut tidak mengurangi makna dari kesederhanaan dalam proses peradilan pada masa Nabi Muhammad.

Sebagaimana yang telah kita pahami bahwa peradilan pada Hukum Pidana Islam sangat sederhana dan tidak serumit pada Hukum Pidana pada hukum positif yang telah diterapkan di Indonesia, sehingga rukun memberi maaf dalam pelaksanaan qishash juga sangat sederhana. Berikut dibawah ini rukun memberi maaf oleh ahli waris terhadap pelaku tindak pidana kejahatan ialah: (a) Aku maafkan; (b) Aku gugurkan tuntutan; (c) Aku bebaskan dari tuntutan; (d) Telah kuberikan; (e) Dan lain-lain".(Raftanzani 2016, 93)

Kata-kata tersebut diatas atau semacamnya harus diucapkan di depan hakim pengadilan. Dengan demikian, gugurlah tuntutan yang telah diputuskan oleh hakim pengadilan karena ahli waris korban dianggap telah memberikan maaf kepada pelaku tindak pidana kejahatan disebabkan kata-kata diatas yang telah diucapkan oleh ahli waris korban.

\section{Pemberian Grasi dan Maaf menurut Teori Keadilan}

Dalam perspektif keadilan, bisa dikatakan bahwa hukuman penjara bagi seorang terpidana bukanlah hukuman yang bisa menimbulkan efek jera karna secara realita banyak sekali terpidana yang keluar masuk penjara bahkan dengan kasus yang sama meskipun beda orang. Secara logika, misalkan seorang anak yang mengetahui ibunya telah dibunuh lalu si pembunuh dipenjara dengan hukuman jangka tertentu hingga akhirnya masa hukumannya habis sehingga ia bisa menghirup udara segar dan anak tadi mengetahui bahwa pembunuh ibunya telah bebas sementara ibunya telah tiada untuk selama-lamanya karna pembunuh tersebut, muncul dalam benak anak tersebut kebencian dan kemarahan karena pembunuh ibunya tidak dihukum dengan hukuman setimpal dan ibunya belum memperoleh keadilan. (Raftanzani 2016, 41)

Dengan demikian, hukuman qishash sebagai wujud keadilan bagi orang yang teraniaya, yaitu dengan cara memberikan kemudahan bagi ahli waris korban untuk membalas secara sepadan kepada pelaku pembunuhan sebagaimana dalam QS. Al-Israa': 33. Allah telah mengharamkan kezaliman atas diriNya dan juga hamba-hamba-Nya karena adil merupakan salah satu sifat Allah yang Maha sempurna.

al-ạ̣kām Vol. 5, Nomor 1, 2020 
Terpidana yang mendapat hukuman qishash lalu kemudian diberi maaf oleh ahli waris korban baik dimaafkan sama sekali atau membayar ganti rugi (diyat), akan sangat bermanfaat sekali terhadap dirinya. Dengan tidak dihukum sesuai perbuatan dirinya artinya bahwa dirinya masih bisa bekerja dan melakukan hal yang bermanfaat untuk diri, keluarga serta orang-orang di sekitarnya. Dengan hukuman penjara sebelum eksekusi hukuman mati membuat dirinya stagnan dan tidak produktif.(Raftanzani 2016, 101)

Sementara itu, berdasarkan teori tentang keadilan yang telah dikemukakan oleh Notonegoro pada bab sebelumnya, yang berbunyi keadilan adalah:

Kemampuan untuk memberikan kepada diri sendiri dan orang lain apa yang semestinya, apa yang telah menjadi hak nya.

Dan juga konsep Teori keadilan oleh Jhon Stuart Mill yang berbunyi:

Sebuah teori yang mengkaji dan menganalisis tentang ketidakberpihakan, kebenaran serta ketidaksewenang-wenangan dari sebuah institusi atau individu kepada masyarakat atau individu lainnya.

Dapat dipahami bahwasanya setiap perbuatan harus dibalas sesuai setimpal atau sepadan. Dalam hal ini pelaku pembunuhan harus mendapatkan balasan sepadan dengan apa yang telah diperbuatnya yaitu telah merampas nyawa orang lain. Balasan sepadan tersebut telah diatur dalam Kitab Undang-Undang Hukum Pidana atau hukum positif begitu pula dalam Al-quran maupun hadis atau disebut Hukum Islam. Terlebih, dalam Hukum Islam dinyatakan bahwasanya membalas perbuatan sepadan menjadi suatu keharusan dan lebih baik jika ada pemberian maaf dari pihak keluarga korban.

Dalam hal ini siapa yang lebih berhak memberikan pengampunan atau maaf terhadap pelaku pembunuhan yang telah merampas nyawa si korban, menurut analisis peneliti berdasar pada konsep yang Jhon Stuart Mill dan juga Notonegoro tawarkan maka perihal maaf menjadi hak dari keluarga korban sebagai ahli waris atau keluarga yang telah kehilangan korban yang tidak akan pernah bisa ia temui lagi dalam kehidupan mereka. Namun, disini keluarga korban selaku warga Negara yang baik harus taat pada pemerintah itu sendiri maka tidak dapat dipungkiri kita juga harus patuh kepada undang-undang yang berlaku di Negara dimana kita hidup dan tinggal. Maka yang dapat peneliti hasilkan dari uraian diatas, Pengampunan atau maaf menjadi hak presiden sebagai pemimpin dan kepala Negara. Dalam memberikan pengampunan dan maaf presiden tidak hanya meminta pertimbangan Mahkamah Agung sebagai lembaga peradilan tetapi juga meminta pertimbangan keluarga korban selaku ahli waris korban yang telah dirugikan dengan kehilangan korban untuk selama-lamanya. 


\section{Kesimpulan}

Pertama, Grasi/pengampunan bukan merupakan upaya hukum. Meskipun grasi dapat merubah status hukuman seseorang, grasi dipandang sebagai hak prerogatif yang hanya ada di tangan Presiden. Grasi/pengampunan tidak terkait dengan penilaian terhadap putusan hakim dan tidak dapat menghilangkan kesalahan terpidana.

Kedua, Memberi Maaf merupakan hal yang diberikan oleh seseorang yang telah di sakiti/ menjadi korban tanpa ada pengajuan terlebih dahulu dan diberikan oleh korban/ keluarganya dalam rangka mencari ridhoNya.

Ketiga, Dapat dipahami beberapa perbandingan dari pemberian Grasi dan Maaf dalam Tindak Pidana Pembunuhan Perspektif Hukum Positif dan Hukum Islam: (a) Kewenangan dalam Memberikan Grasi terletak kepada Presiden selaku Kepala Negara, sementara itu memberikan Maaf merupakan kewenangan dari keluarga korban selaku ahli waris korban; (b) Dalam hal siapa yang berhak memberikan pertimbangan. Hukum Positif menyatakan bahwa ketika memberikan Grasi kepada pelaku tindak pidana pembunuhan harus mempertimbangkan keputusan Mahkamah Agung. Sementara itu, dalam hal pemberian Maaf, yang berhak memberikan pertimbangan adalah semua keluarga korban selaku ahli waris korban baik itu laki-laki maupun perempuan; (c) Berdasar pada konsep Keadilan yang ditawarkan Jhon Stuart Mill pada uraian sebelumnya, dalam memberikan pengampunan dan maaf presiden tidak hanya meminta pertimbangan Mahkamah Agung sebagai lembaga peradilan tetapi juga meminta pertimbangan keluarga korban selaku ahli waris korban yang telah dirugikan dengan kehilangan korban untuk selama-lamanya. Disitulah letak keadilan menurut peneliti.

\section{Saran}

Berdasarkan hasil penelitian ini ada beberapa yang harus di perhatikan sebagai sumbang pemikir peneliti untuk dijadikan sebagai bahan masukan dan saran-saran antara lain:

Pertama, Presiden agar dapat mempertimbangkan dengan sungguh-sungguh dan matang dalam memberikan pengampunan atau maaf kepada pelaku tindak pidana pembunuhan.

Kedua, Presiden sebagai Kepala Negara dalam hal pengajuan grasi atau pengampunan oleh pelaku pembunuhan tidak hanya meminta pertimbangan dari Mahkamah Agung sebagai lembaga peradilan tertinggi yang menyangkut putusan hakim akan tetapi juga ahli waris korban yang telah dirugikan karna mereka tidak akan pernah bertemu dengan anggota keluarganya yang menjadi korban untuk selama-lamanya.

al-ạ̣kām Vol. 5, Nomor 1, 2020 


\section{Daftar pustaka}

'Audah, Abd. Qadr. 1963. At-Tasyri' Al-Jinaiy Al-Islamiy, Cet. 3. Kairo: Maktabah Dar AlGurubah.

Al-Fannani, Zainuddin bin Abdul Aziz Al-Malibari. 2013. Penerjemah Moch Anwar, Bahrun Abu Bakar, Anwar Abu Bakar. Terjemahan Fathul Mu'in Jilid 2. Bandung: Sinar Baru Algensindo.

Ali, Mahrus dan Syarif Nurhidayat. 2011. Penyelesaian Pelanggaran HAM Berat (In Court System Dan Out Court System). Jakarta: Gramata Publishing.

Ali, Zainuddin. 2010. Metode Penelitian Hukum. Jakarta: Sinar Grafika.

Arifin, M. Amin. 2016. "Pidana Mati Menurut Hukum Nasional Dalam Hubungannya Dengan Hukum Islam." Jurnal Al-Ahkam (Jakarta) Vol. 4 Nom.

Chazawi, Adami. 2002. Pelajaran Hukum Pidana. Jakarta: PT RajaGrafindo Persada.

Dillah, Suratman dan Philips. 2013. Metode Penelitian Hukum. Bandung: Alfabeta.

Gustiani, Diah, Dkk. 2013. Hukum Penitensia Dan Sistem Pemasyarakatan Di Indonesia. Bandar Lampung: PKKPUU FH UNILA.

Huda, Ni'matul. 2013. Hukum Tata Negara Indonesia. Ed.Revisi. Cet.8. Jakarta: Rajawali Pers.

Idris, Imam Syafi'I Abu Abdullah Muhammad bin. 2013. Ringkasan Kitab Al-Umm. Penerjemah Imron Rosidi, Amirudin, Imam Awaluddin. Jakarta: Pustaka Azzam.

Katsir, Ismail bin. 2004. Tafsir Ibnu Katsir, Terj. Abdul Ghaffar, et. Al., Jilid 4. Bogor: Pustaka Imam Asy-Syafi"i.

Khallaf, Abd al-Wahhab. 1998. Al-Sultah Al-Salas Fi Al-Islam: Al-Tasyri Al-Qada Al-Tanfiz. Cet. II. Kuwait: Dar al-Kalam.

Lestaluhu, Kayum. 2017. “Eksistensi Grasi Dalam Hukum Pidana Nasional Legal Pluralism” Volume $7 \mathrm{~N}$.

Muhammad, Abu Qasim al-Husain Ibn. n.d. Al-Mufradat Fii Garib Al-Qur'an. Beirut Libanon: Daar al-Ma'rifah.

Munajat, Makhrus. 2009. Hukum Pidana Islam Di Indonesia. Yogyakarta: TERAS.

Nasional, Departemen Pendidikan. 2008. Kamus Besar Bahasa Indonesia. Jakarta: Pusat Bahasa.

Priyanto, Anang. 2012. Hukum Acara Pidana Indonesia. Yogyakarta: Ombak.

Purbalin, Paisol. 2015. Implementasi Konsep Hukum Qishash Di Indonesia. Jakarta: Sinar Grafika.

Raftanzani, Anshari. 2016. Pemberian Grasi Dan Maaf Dalam Tindak Pidana Pembunuhan (Studi Komparatif Antara UU No. 5 Thn. 2010 Tentang Grasi Dan Hukum Islam). Sumatra Utara: Pasca Sarjana Universitas Islam Negeri Sumatra Utara Medan.

Sabiq, Sayyid. 2012. Fiqih Sunnah. Jakarta: Pena Pundi Aksara.

Shihab, M. Quraish. 2002. Tafsir Al-Misbah: Pesan, Kesan Dan Keserasian Al-Qur'an, Jilid 5. Jakarta: Lentera Hati.

Sofian, Ahmad. 2018. Ajaran Kausalitas Hukum Pidana. Jakarta: Kencana. 
Sunggono, Bambang. 2013. Metodologi Penelitian Hukum. Jakarta: PT RajaGrafindo Persada. Supranto, J. 2003. Metode Penelitian Hukum Dan Statistik. Cet. I. Jakarta: PT Rineka Cipta.

Susanti, Dyah Ochtorina dan A'an Efendi. 2015. Penelitian Hukum (Legal Research). Jakarta: Sinar Grafika.

Syaikh, Abdullah bin Muhammad bin Abdurrahman bin Ishaq Alu. 2017. Lubabut Tafsir Min Ibnu Katsir. Tafsir Ibnu Katsir. Penerjemah M. Abdul Ghoffar. Jakarta: Pustaka Imam Asy-Syafi'l.

Undang-Undang No. 22 Tahun 2002. n.d.

Undang-Undang Nomor 14 Tahun 1985 Tentang Mahkamah Agung (Lembaran Negara Republik Indonesia Tahun 1985 Nomor 73, Tambahan Lembaran Negara Republik Indonesia Nomor 3316). n.d.

Yusuf, Slamet Effendy dan Umar Basalim. 2000. Reformasi Konstitusi Indonesia Perubahan Pertama UUD 1945. Jakarta: Pustaka Indonesia satu.

Zein, Satria Efendi M. 2008. Ushul Fiqh. Jakarta: Kencana. 